\title{
DRESSING IN OTHER PEOPLE'S CLOTHES. CHANGES IN CLOTHING DURING EVANGELIZATION OF RAPA NUI: A DIALOGIC EXPRESSION (1864-1877)
}

\author{
VESTIR CON ROPAS AJENAS. LOS CAMBIOS EN LA VESTIMENTA DURANTE \\ LA EVANGELIZACIÓN DE RAPA NUI: UNA EXPRESIÓN DIALÓGICA \\ (1864-1877)
}

\author{
Antonia Mardones ${ }^{1}$ y Andrea Seelenfreund ${ }^{1 *}$
}

\begin{abstract}
In all human societies, textiles play important roles in social, economic, and religious life. As in other Polynesian societies, on Rapa Nui (Easter Island) in the second half of the $19^{\text {th }}$ century, textiles were important locally and served, above all, as objects of exchange with foreign visitors. This article examines cultural transformations that occurred on Rapa Nui, as reflected in the use and signification of textiles, particularly in the use of introduced cloth and clothing during the times of the first missions and the first colonial agents. Our analysis is based on information taken from missionary writings and from the reports of travelers and explorers who visited the island during that period. Understanding that material culture cannot be separated from the cultural practices in which it is embedded, our analysis will focus on accounts referring to material objects as elements that reflect the social and cultural transformations of the historic context in which they were created. We argue that the islanders redefined Western textiles that were introduced, using them in ritual contexts appropriate to the island's culture. European textiles acted as status markers within a new social organization, and also served as sociopolitical markers among island groups (Christian converts and non-converts).
\end{abstract}

Key words: Easter Island, material culture, christianization, Western textiles, cultural transformation.

En toda sociedad humana los textiles, desempeñan roles importantes en la vida social, económica y religiosa. Al igual que en otras sociedades polinesias, en Rapa Nui (Isla de Pascua) en la segunda mitad del siglo XIX, los textiles eran de importancia y fueron por excelencia objeto de intercambio con los visitantes extranjeros. El presente artículo indaga en la problemática de las transformaciones culturales en Rapa Nui que se ven reflejadas en el uso y significación del textil, particularmente en la utilización de las telas introducidas durante los tiempos de la primera misión y los primeros agentes coloniales. El análisis se basa en datos tomados de los escritos misioneros e informes de viajeros y exploradores de la época que visitaron la isla. Entendiendo que la cultura material no puede separarse de las prácticas culturales en las que están insertas, nuestro análisis se centra en los relatos acerca de los objetos materiales como elementos que reflejan las transformaciones sociales y culturales del contexto histórico en el que se crearon. Afirmamos que los isleños redefinieron los textiles occidentales introducidos, dándoles usos en contextos rituales apropiados de la propia cultura isleña, donde las telas europeas oficiaron como marcadores de estatus dentro de una nueva organización social, sirviendo también como marcadores entre grupos sociopolíticos (conversos y no conversos).

Palabras claves: Isla de Pascua, cultura material, cristianización, textiles occidentales, transformación cultural.

Textiles have played major roles in the social, economic, and religious lives of humans throughout history. They are a fundamental part of our material culture and fulfill a wide variety of purposes, both functional and symbolic. Textiles were also an important component of ancient economic and social relations, and essential elements in many aspects of daily life
(Weiner and Schneider 1989). In almost all human societies, people have used forms of dress to define who they are and which group they belong to (Hendricksen 1991; Medlin 1991; Schneider 1987; 2006). Textiles have also been used to demonstrate power or exercise control, identify "the other", and assign individuals to positions within a social hierarchy (Martin 1986;

$1 \quad$ Escuela de Antropología, Universidad Academia de Humanismo Cristiano, Santiago, Chile. antonia.mardones@gmail.com. *autora correspondiente: aseelenfreund@academia.cl 
Owyong 2009). Thus, textiles have been valuable objects in commercial relationships and have often functioned as basic elements in diplomatic relations between cultures and societies (Cory-Pierce 2005; Schneider 1987, 2006).

Several authors (Cory-Pearce 2005; Sturma 1998; Tcherkézoff 2003; Tcherkézoff 2012) have proposed that European textiles in the South Pacific were important objects of mediation in exchanges between islanders and early Western explorers. The act of dressing and undressing the body deeply shaped how Europeans and South Pacific peoples reacted to each other. Also on Rapa Nui ${ }^{1}$, in the initial encounters between islanders and foreigners, textiles served as mediating objects, as they had the capacity to articulate the autochthonous with the foreign, thereby mediating the frontiers in a situation of cultural contact (Seelenfreund and Mardones 2018:35). The cultural encounter and contestation implied by the contact between Europeans and South Pacific islanders brought with it the construction of alterities that developed gradually as the process unfolded.

The history of the changing use of indigenous textiles and the introduction of Western ones is linked to the history of Christian conversion in the Pacific. The adoption of imported textiles and forms of Western dress were not simple colonial impositions by foreign missionaries upon a passive local island population, or only repressive forms of domination of 'savage bodies'. On the contrary, Western cloth and clothing were actively sought after by the South Pacific islanders, as these materials were a sign of the foreigners' efficacy and power (Seelenfreund and Mardones 2018). As Bolton (2003) suggests, indigenous attire was much more than cloth that covers the body; it included an array of adornments and body modifications that marked both gender and status. These included: necklaces, earrings, bracelets, and ankle cuffs made of shells, fiber, and seeds; tattoos, nose perforations, head bands and turban-like coverings, body paint and coconut oil, among other things. The attire, accessories, and body modifications were not a question of personal style; they were governed by collective codes regarding gender, rank, and stage of life. Küchler and Were (2005) note that the islanders' conversion to Christianity and adoption of foreign dress were acts of material translation that reflected the mixing of elements of both their own and foreign cultures. They were a way of making sense of the new scenario, allowing the shaping of identity in the midst of changing conditions. Just as cloth played a central role in translating new cultural values for Polynesian societies, garments were essential in the evangelizing work of the missionaries, because dressing the islanders was one of their core concerns. Clothing thus became an instrument of conversion, an expression of a new way of thinking and acting. The missionaries saw the Western Christian way of dressing as an indicator of 'civility', and thus seeing the islanders 'dressed' offered material proof that they had been 'truly converted'. However, the predominant forms and hegemonic signifiers of Christian virtue contained in the introduced clothing were transformed through appropriation by the bodies of the male and female islanders. In this way, they were not only materials and signs of Christian domesticity, but also became imbued with the indigenous values of sacredness and rank (Jolly 2014; Küchler and Were 2005). Throughout Polynesia, the new textiles introduced were associated with the efficacy and power of the foreigners, and thus the islanders were anxious to appropriate these garments for themselves. Küchler and Were (2005) indicate that this is linked to a strategy of contending with change, in which we see both indigenous and foreign cultural elements being reorganized.

Based on the symbolic and ritual importance of textiles throughout Polynesia (Babadzan 2003; Tcherkézoff 2003; Thomas 2003), this article examines cultural transformations on Rapa Nui reflected in the use and significance of a materiality, in particular the cloth and clothing introduced by Western missionaries and merchants. We will focus on the cultural transformations experienced by the Rapanui people during the period of colonization and early Christianization (1864-1877), when the first Western residents settled on the island, i.e., the missionaries of the Sacred Hearts of Picpus. This period begins with the arrival of the lay brother Eugène Eyraud in early January 1864, and his nine-month residency on the island, continued by the installation of the mission in March 1866, and lasts until the order abandoned the island on the $6^{\text {th }}$ of June, 1871 accompanied by 275 islanders (Fischer 2005:113). We complemented with the analysis of the accounts provided by the journals of the visit of Alphonse Pinart and Pierre Loti the first foreign visitors to stop on the island after the assassination of the French merchant J.B. Dutrou Bornier in 1876, who had settled on the island.

We analyze the cultural transformation particularly the topic of nakedness vs. being dressed as an 
important part of the evangelization process, using a historical anthropology framework analyzing unpublished archival documents such as the letters of the Catholic missionaries compiled by Americo Cools and expedition journals from the end of the $19^{\text {th }}$ century ${ }^{2}$.

\section{Evangelization, colonial domination and cultural control}

The present article addresses the cultural transformations experienced by Rapanui society in the period of Christianization and early colonization. Our theoretical framework is based on Balandier's (1973) definition of the "colonial situation", in which Western European societies established an economic, political and cultural dominance over smaller cultures. As pointed out by the author, a colonial situation is established when subordinate relations are exercised by a racial minority, culturally differentiated from an autochthonous or native majority (Balandier 1973). For his part, Aguirre Beltrán (1991) poses that the actors in a colonial situation of domination are in opposing relationships, where the dominant group will exercise economic and political control over a common territory that in the past was exercised by the native population (Aguirre Beltrán 1991).

Finally, in order to address the cultural transformations during this period, we focus on Bonfil Batalla (1983, 1991), who reflected on the dynamics of cultural change, and the capacity of a social group to produce and reproduce cultural elements. The focus is placed on how groups adapt to external circumstances in the case of colonial domination. Making group choices within the colonial rule, does not imply that the group is not subjected to cultural domination (Bonfil Batalla 1991). The author maintains that relationships between culturally differentiated groups, involve different spheres of culture. These cultural spheres are articulated on the basis of cultural elements and the decisions that the group takes regarding these. These cultural elements may be part of their own culture or else be foreign cultural elements. The former are made up of their cultural heritage; the latter constitute elements that the group has neither produced nor is capable of reproducing, but that has become part of its social life in the context of permanent contact with another social group; in our case, the evangelizing engagement.
The author defines cultural control as a system, that articulates a number decision making mechanisms of the social group regarding own and foreign cultural elements. Cultural control is thus a society's capacity to decide on which cultural elements are necessary to formulate and carry out social objectives. In the contexts of colonial domination, a social group will have differential access to certain cultural areas. We will see the coexistence of the group's own culture with the culture of the outsiders. Of the four cultural areas defined by Bonfil Batalla (1991), that are dependent of the group's decision-making capacity, here we will focus on the concept of appropriated culture, defined as the decision-making capacity that the group acquires regarding foreign cultural elements.

\section{Missionaries in Polynesia}

The missionary experience in Polynesia included Protestant and Roman Catholic religious congregations. The former had its main origins in the British imperialist expansion and domination of the sea in the 18th and 19th centuries, which saw in the Polynesian islands a tremendous opportunity to establish new overseas territories and disseminate the Word of God among the heathens (Delaire 2005; King 2011). The European intervention in the Pacific region was determined both by rivalry among imperialist powers and by competition for 'saving souls' among Protestant and Catholic missions. It was during the Restoration that, in France, the nascent order of the Sacred Hearts of Jesus and Mary (also known as the Picpus fathers) decided to expand their evangelizing work abroad (Caranci 1976; Delaire 2005), in particular to the lands still submerged in the 'darkness of idolatry.' Their vocation focused especially on Polynesia, with the aim of fighting on two fronts: first by extirpating the 'heresy' installed by the Protestants, and then by eradicating the 'superstitions' of the local population. Concerning the Catholic evangelization, the decree signed by Pope Leon XII in 1833 divided the islands of the Pacific into two oceanic vicariates: the eastern Polynesian vicariate, granted to the congregation of the Sacred Hearts (Picpus), and the western Pacific vicariate which included all Micronesia and Melanesia and Polynesia westward of the Cook Islands, left in the hands of the Marist Brothers (Laracy 1976). The former installed themselves in the Gambier Islands (1834), as they were expelled from Tahiti by Queen 
Pōmare Vahine and by the Protestant reverend, Pritchard. For their part, the latter disembarked at Futuna in Western Polynesia (1837), sailing beyond New Zealand (1838) to install themselves in Fiji, Samoa, and New Caledonia (1844) (Caranci 1976; Tippet 2005).

The Catholic missionaries set up centralized missions or 'missionary theocracies' (Laux 2000) that contributed to the concentration of power in the hands of certain local chiefs. In some cases, they operated almost as strong-armed 'missionary dictatorships' through the use of force and violence (Caranci 1976). A paradigmatic case can be found in the Sacred Hearts order, particularly in the mission on the Gambier Islands, where Father Honoré Laval with the aid of Father Caret and a council of native chiefs, set up a closed world by controlling the pearl market, and gaining power as a true theocratic dictatorship. For the missionaries converting the local chiefs was often of prime importance for it meant securing the support from the whole community; at the same time missionaries were instruments of native chiefs who used them to their own advantage to gain some of the white man's mana in exchange (Ernst and Ainsi 2016). It was one of Laval's disciples who was ultimately appointed head of the mission on Rapa Nui (Caranci 1976).

\section{Missionaries of the Sacred Hearts of Jesus and Mary on Rapa Nui (1864-1871)}

The first missionaries to arrive on Rapa Nui were the missionaries of the Catholic Congregation of the Sacred Heart of Jesus and Mary (Picpus fathers). The very first was Friar Eugène Eyraud, a French carpenter who had been living in the Chilean city of Copiapó and who had entered the order late in life to dedicate himself to missionary work. After a period of training at the main mission on Mangareva he disembarked on the shores of Rapa Nui on January 2,1864 , having sailed from Tahiti with a group of six Rapa Nui islanders rescued from slave ships, including Manurangi, the son of one of the most prestigious chiefs of the "Miru" clan. Eyraud remained on the island for nine months, to impart the teachings of the Catholic faith to the islanders (Edwards 1919).

The priests of the Sacred Hearts order had forged ties with the Chilean government long before they ever set foot on Rapa Nui. The port of Valparaíso was used as a point of contact and provisioning of the missions established in the remote Pacific islands. The order set up a post in Valparaíso in 1834, in order to direct from there their missionary work in the Pacific under the direction of Father Juan Crisostome Liausu (Departamento de Historia Militar 2006:62). For their part, fathers Laval and Caret left for Tahiti and then continued on to Mangareva to take up their own missionary work.

The first sojourn by Friar Eugène Eyraud would prepare the ground for the later installation of the mission on the island. After nine months, Eyraud returned to Valparaíso, where he wrote a report about his experience on Rapa Nui to the Vice Provincial, Father Pacôme Oliver. The bishop decided to found a mission on Rapa Nui, appointing R. Father. Hippolyte Roussel as the first priest in charge. Roussel had begun his missionary career in 1854 as a disciple of Father. H. Laval, on the islands of the Tuamotu Archipelago, the Marquesas and Gambier Islands (Mangareva) (Englert 1996). In April 1865, Friar Eyraud sailed to Tahiti, the seat of the Apostolic Vicariate and residence of Bishop Monsigneur Stephanus (Tepano) Jaussen. There, he met with Father Hippolyte Roussel and the two sailed from Papeete (Tahiti) to the Mangareva mission led by Father Honoré Laval. On March 23, 1866, the schooner Favorita reached Rapa Nui, bearing Roussel, Eyraud, and three Mangarevian catechists, who installed the Catholic mission at Hanga Roa and with it began the second stage of evangelization defined by Muñoz (2017) ${ }^{3}$, which would last until 1871. In November 1864, French Captain Jean-Baptiste-Onèsime Dutrou Bornier arrived, commanding the schooner Tampico, and bringing Father Gaspard Zumbohn and Friar Théodule Escolan, both also Sacred Hearts missionaries. They also brought the first European fruit trees, seeds, and domestic animals (Edwards 1918; Englert 1996; Foerster et al. 2013). Two missions were founded on the island - one in Hanga Roa, led by Father Roussel, the other in Vaihu directed by Father Zumbohn - as well as a residential school for boys and another for girls, called 'pupuran $a^{\text {'4 }}$. The two missions served as an attractor to some islanders, who set up residences around them. The missionaries had to deal with a serious tuberculosis epidemic on the island that decimated the island population in just a few years.

In late 1868, Dutrou Bornier returned to the island, to live in the Mataveri district. Together with the missionaries, he helped to found the town of "Santa María de Hanga Roa", where they concentrated most 
of the population. The French merchant proclaimed himself President of the 'State Council of the Villa de Santa María de Rapa Nui'. While at first the relationship between the missionaries and the merchant was based on mutual aid, this did not last, and their intensely opposing interests came to the fore, ultimately leading to armed conflict between the parties. In 1871, a date that marks the beginning of the third stage of evangelization (Muñoz 2017), owing to the growing dispute between the missionaries and Dutrou Bornier, the Bishop of Tahiti, father Roussel and father Escolan determined that their stay on the island became untenable, and decided to leave, along with any islanders who wanted to accompany them (Fischer 2005). They left the island bound for Mangareva with almost 200 converts. At the same time, another 109 Rapa Nui were sent by Dutrou Bornier to work on Brander's Tahitian plantations (Conte 1994; McCall 1996; Muñoz 2017). By then, Father Zumbohn had also abandoned the island.

From 1872 to 1876 , the island was in the hands of Dutrou Bornier, who proclaimed himself King Jean I, and ruled with his wife, Koreto Pua Akurenga, whom he had arbitrarily named queen of Rapa Nui. The merchant had formally established the BranderBornier company, turning the island into a sheep ranch, with local residents serving as its laborers. He died under 'mysterious circumstances' in 1876 (see Muñoz 2017), ushering in the period that Englert (1996:99-103) called 'ecclesiastical abandonment', which preceded his arrival on the island in 1935.

\section{Rapa Nui Cultural Elements during the Missionary Period}

The missionaries viewed the islanders as lacking any form of religious worship, and noted that this facilitated their evangelizing work. However, the missionaries describe a variety of practices that point to a Polynesian worldview and reveal the persistence of cultural elements that may not have been expressed in formal religious practices, and therefore difficult for the missionaries to interpret. First, Rapanui society was organized around some pan-Polynesian prohibitions, known as tapu, which protected people from a powerful natural force, called $m a n a^{5}$. Consequently, we read in the missionaries letters that 'there was, however, a practice that was tied to religious sentiment: it was respect mixed with fear for certain sacred objects called 'tapu': this sentiment was habitually maintained by those for whose benefit it revolved around' (Cools 1973 par 349:131). For his part, in 1870, Ignacio Gana, commander of the Chilean ship O'Higgins commented, that a sick four year old child, son of a chief who had died in Peru and who defended:
his hair, which they wanted to cut to lower the fever that cost him his life. It is curious to see that a child so young was already imbued with the ideas of tapu and even tried to cling to them at the most critical time of his life (Gana 1870, in Foerster et al. 2013:444).

The child known as Rokoroko He Tau, or Kerekorio Munurangi, was baptized by the missionaries as "Gregorio" (ca. 1855-1867). He was the grandson of ariki Nga' ara and therefore in direct succession of the royal lineage of the Miru tribe (Moreno Pakarati 2011) and was called "petit chef" by Roussel. He would receive the first offerings of the season's harvests. In September 1866, Roussel writes in a letter to the Bishop in Tahiti,

I hope that in the future, when sufficiently instructed he will serve the mission [...] Unfortunately for us and for his predecessors, he has no other kingly authority than his name: they bring him the first fruits of yams and octopuses and other gestures of the kind are offered to him, but he has no voice in the administration of the country (Letter from H. Roussel to Mons. T. Jaussen. Cools 1973: SS.CC. 132-140).

These two quotes reveal that the Rapa Nui worldview had not 'disappeared' as a result of the kidnapping of the bulk of the island's population by Peruvian, Chilean and Spanish ships in 1860 (Godoy 2017; Maude 1981). The fact that the child refused to have his hair cut speaks of the persistence of deeprooted beliefs of the native culture. Despite the new religion, the Rapanui of the time honored certain taboos and protested when these where breached. This supposed loss of tradition and lack of a system of religious worship, according to the missionaries, was evidenced by the absence of an 'organized ritual 
system'. As with the persistence of ritual restrictions, the missionaries describe the maintenance of a number of symbolic elements that are manifested in material aspects within Rapa Nui culture. For example in a letter written by Gaspar Zumbohn to MRP Rouchouze in Paris we read:

\section{(...) he found Kutano (Torometi) with an insignia of paganism (...) Take it, said Torometi, removing the feathers, I had put it on for the last time only to entertain myself and give it to you afterwards (...) Torometi does not speak anymore of the objects that were once so treasured by him (Gaspar Zumbohn to MRP Rouchouze in Paris. 1868. Cools 1973 par 215:76).}

These lines exemplify how, within Rapa Nui culture, certain material elements were related to what the missionaries identified as 'pagan customs', and which we identify as part of a Polynesian ontology. In the case of Torometi, a chief, his garments and objects were correctly identified by the missionaries as insignia of the high status he possessed. By the same token, we could argue that certain accessories, such as a feather headdress or a wooden staff, were possessed of powerful mana, as Roussel relates: 'Some young people of Vaihu (...) find the wooden god and two staffs of the pagan authority. Mataveri is furious that the pagan god had been stolen' (Account by $\mathrm{H}$. Roussel 1870, addressed to MGR Jaussen. Cools 1973 par 57:21).

Textiles are another element of material culture found taking part in Rapanui rituals, especially in funerary rites. Eyraud in his diary claims that he had seen no

...religious rites related to death. When a person is ill, the entire treatment consists of removing them from the hut during the day, then putting them back inside at night (Eyraud diary, December 1864. Cools 1973 par 57:21).

However, in the same sentence he states,

If the sick person takes their dying breath, they are wrapped in a grass mat slightly longer than the body, the mat is tied with 'purau' fiber, and the bundle is placed in front of the house, on the side facing the ocean; these bodies wrapped in mats are placed on a pile of stones or on a kind of wooden trestle. The head pointing in the direction of the ocean (Eyraud diary, December 1864. Cools 1973 par 57:21).

While this extract of the diary shows how the celebration of funerary rites associated with the ahu-moai complex had been abandoned, the ritual still presented elements of the Polynesian and Rapa Nui cultures. There is an obvious continuity in the treatment of the dead, which lay exposed to the air and sun, wrapped in mats, in a ritual in which the essence of the person abandoned the body through the fibers.

\section{Conversion to Christianity}

The evangelical work of the Sacred Heart missionaries carried out on Rapa Nui was guided by six fundamental principles or approaches: (1) the use of violence, (2) territorial relocation, (3) material gifts, (4) healing of the sick, (5) suppressing local beliefs, and (6) clothing the natives. These principles were applied in different intensity. We briefly show here how these were applied to the island context, before focusing in detail on the sixth principle.

The use of violence for example was exercised solely by Father Roussel and disapproved of by the other missionaries. The second principle, relocation of the population, was carried out in alliance with local chiefs (see Sahlins 1985), where these saw in these alliances a way of increasing their own power. This strategy was not successful on the island, owing to the premature deaths of the chiefs who had supported it. However, the process of evangelization ultimately succeeded through the mission schools for orphaned children, called pupuranga. This also favored territorial reorganization of the islanders into a single town and abolished their own forms of territorial organization based on kinship group or mata, with the converts serving as active agents in the propagation of the new faith.

The third principle of evangelization was based on handing out material gifts, in order to attract islander attention, particularly needles and thread were the most desired by the islanders. Thus we read in Father Zumbohn's accounts, 'I must add, then, that we cultivated carefully that childlike docility (...) Seeing, to our satisfaction, how sensitive [they were to] the slightest sensation, we encouraged their passion for 
these goods by distributing small tokens' (Zumbohn, in Cools 1973 par 383:151). The fourth principle was used by Zumbohn as a conversion strategy. He went out to visit the sick with a medicine box, but when the islanders realized that this box could not cure all illnesses, meaning that its mana was not powerful enough, or that it lacked mana entirely, they soon lost interest in it. The fifth principle of evangelization was to suppress local beliefs by eradicating the $\operatorname{tap}^{6}$ placed on certain material objects or places, by systematically violating the prohibitions in order to prove that they suffered no harm for doing so. The missionaries attempted to make the islanders see 'how childish' that belief was, demonstrating to them that nothing happened when the tapu were violated, as we read in this letter: 'We missionaries only had to destroy the superstition of the 'tapu' that the chiefs pronounced about some portions of land that they wanted to preserve for certain uses' (Annals of the Sacred Heart 1880, II. Cools 1973 par 352:132). However, this strategy did not have the intended results. When the missionaries violated the tapu without suffering any misfortune, the Rapa Nui did not stop believing in tapu, but instead looked upon the missionaries as beings possessed with a powerful mana. The islanders interpreted those acts as showing that the missionaries' mana was greater than that of the chiefs who had imposed the tapu. The Christian god therefore grew in power. Under the Polynesian logic, in which the pantheon of gods is imbued with status and rank, the Christian god began to be positioned as the highest-ranking deity, For example father Roussel, when surround by a closed group of islanders feeling threatened,

out of prudence, and following the advice of one indigenous islander, who from the beginning had defended him, he climbed a nearby rock and this simple precaution saved him, as he found out later the rock was 'tapu' (sacred), and the indigenous people out of superstition did not dare to damage it (Felix Jaffuel, in Foerster et al. 2013:236).

At some other time Father Rossell mentions that their status as holders of power and mana was saved when they could provide new supplies from afar (undated report by H. Roussel, Cools 1973 par 208:73). The Rapanui saw in these capacities the supernatural power of the foreign settlers, reinforcing their mana by their ability to attract ships laden with food, livestock, material goods and importantly clothing.

Central to our study is analyzing the sixth principle of evangelization, the act of "clothing the natives". In the missionaries' accounts, when referring to indigenous nudity islanders are described as savage and barbarous, reducing men to the state of beasts. Clothing the Rapa Nui people became a central concern of evangelization, as it became synonymous with civilization, and nudity synonymous with savagery. In the following excerpts written in 1870, Father Albert Montiton observes that, when dressed, the native women began to display the virtues of 'discretion' and 'modesty' expected from Western women. In this way, they became "civilized." When setting foot on the island he describes the population, particularly the women with these words:

The grace of the sacraments had a noticeable influence on the customs of the indigenous people in general (...) the discretion and modesty of the girls and young women who had for a long time been wanton and dissipated. Some among them had truly, firmly been converted (...) From my first descent to the shore of the island (...) I was struck by the modesty and reserve of the young women and people of that sex in general. In the church and in the school, their bearing, like that of the men, is perfectly correct and instructive (Albert Montiton, 13 March, 1886. Cools 1973 par 542:213).

Correct behavior, as expressed in modesty and reserve, became an element that expressed the triumph of the 'civilizing mission'. Thus, as in other Polynesian islands, clothing the locals became a central axis of evangelization and an indicator of Christian conversion, as it was seen by the missionaries as a material reflection of Western morality. Evangelization on Rapa Nui, as we have seen, was the responsibility of Catholic missionaries, and one of the axes of conversion was to clothe the indigenous people. On the other hand, the appropriation of Western textiles by the islanders did not occur in the same way as on islands served by Protestant missionaries. As no European women had arrived with the priestswomen who could have taught the islanders how to 
make and wear Western garments-the islanders could not obtain direct knowledge of this skill. Also, the majority of the garments used in this period by the Rapanui came ready-made, either brought by the missionaries or traded from ships, and most of these were military uniforms.

The Catholic missionaries were very interested in the quantity of converts, and perhaps to a lesser degree, in the quality of their conversion. The mission on Rapa Nui was no exception to this rule. The letters of the missionaries testify to the importance given to quantifying converts. Conversion itself was proven in the sacrament of baptism; in fact, for this reason Father Roussel wrote to his superiors in Tahiti after the death of Eyraud in 1868, relating that all islanders now professed the Christian faith. But this only meant that all of them had been baptized, which does not mean that they had stopped engaging in certain practices that the missionaries described as 'pagan.' As we shall see, one of those practices was dressing in the 'pagan' style.

\section{Textiles in the Mission}

In regard to textiles, the missionaries try to make a clear distinction between the naked and the clothed, using Western standards as their point of reference. In some of their writings, they refer to the Rapanui as 'unclothed', despite the fact that they go on to describe what they are wearing. For example Brother Eyraud, in the his initial description of the population writes,

They are threatening, armed with spears; most of them are entirely unclothed. The feathers they wear as adornment, the paint on their bodies, their wild cries, all of which gives them a fearful appearance (...) they all seem alike at first glance. Everyone uses the same uniform (...) the cloth with which the women cover themselves is usually made of some kind of straw; that of the men is made of another material (...) all of them have the same outfits. This uniform is also extremely simple (Brother E. Eyraud. Cools 1973 par 39:15).

These contradictory accounts are further reinforced by another statement from Brother Eyraud emphasizing the importance of clothing to the Rapanui:

\begin{abstract}
At another time, I met a tailor who divided the men into two classes: people who cover themselves and people who dress themselves. It is evident that the inhabitants of Easter Island belonged to the second class. Covering themselves is unimportant to them, and the purpose is not to protect themselves from the heat or cold; what most interests them is adorning themselves (Brother E. Eyraud. Cools 1973 par 54:20).
\end{abstract}

Islanders often exchanged items with the priests and friars to obtain textiles, as related by father Zumbohn, who states '[when] we intervened as interpreters and peacemakers (...) we even had to sacrifice some of our outfits to replace those that, they said, had been taken from the people of Sr. Dutrou Bornier. Peace was restored.' (Theodule Zumbohn to M. Jaussen, undated. Cools 1973 par 314:114 ), or when Father Roussel writes: 'he (Dutrou Bornier) began to purchase, for [the price of] some lengths of cloth, land from the true owners or third parties' (Father Hippolyte Roussel. Cools 1973 par 454:177), bearing witness in this practice to the value of textiles in Rapanui society when the missionaries arrived.

Bartering for textiles with the crews of visiting ships was common practice throughout the mission period, which shows that this way of relating with foreign visitors had a longstanding history (see Seelenfreund and Mardones 2018), and is well exemplified in the following two paragraphs from the report of the commander of the O'Higgins, a Chilean navy vessel that visited the island in 1870:

The indigenous people surrounded (the crew members who had disembarked), giving a very warm welcome, accompanying them and anticipating their every desire. The wharf was full of people. The cries and shouts that were heard when a ship came into port would have made them think their attitude was hostile. Many of them came on board by swimming, bringing on their heads or on small pieces of wood, a variety of objects for swapping (Viaje de la O'Higgins a la Isla de Pascua. Instrucciones y Diarios Carta del Ministro de Guerra y Marina Don Francisco Echaurren al Comandante 
General de Marina ${ }^{7}$. 1870. In Foerster et al. 2013:419).

More local residents came on board the ships in the boats of the missionaries and Captain Bornier. Almost all of them brought trade goods, little stone and wooden statues, chickens, snails, sweet potatoes, chief's scepters, and so on, and what they most ask for in exchange is clothing, trousers. They prefer canvas cloth and are mistrustful, not handing over the object until they receive the trade (...) For a rabbit or a wooden monkey they want jackets, shirts, and trousers. (Viaje de la O'Higgins a la Isla de Pascua. Instrucciones y Diarios Carta del Ministro de Guerra y Marina Don Francisco Echaurren al Comandante General de Marina.1870. In Foerster et al. 2013:420).

Another common theme in the missionaries' accounts is the theft of Western hats and garments, as it also implies a continuity in the way Rapanui people related to foreigners. For example, Brother Eyraud writes:

But these defenders of property had been careful to claim everything they found within their reach. One wore my hat proudly, another rather dexterously put on my coat (...) All of a sudden, I felt them taking off my hat. At the same time, without having a chance to look around me, two or three vigorous arms took, from me, with the same ease, and then separated from each other, my overcoat, my waistcoat, my shoes. (...) when I was able to look around me, I saw my looters decorated with their plunder (brother E. Eyraud, 1864. Cools 1973 par 45:17).

Both theft and textile exchange speak of longstanding habits of relating with foreigners in regard to textiles, which was recorded from the very first visitors to Rapa Nui in the $18^{\text {th }}$ century (see Seelenfreund and Mardones 2018), and persisted throughout the mission period.

The missionaries further highlighted the way in which the Rapa Nui imitated European forms of attire-how they wore sailors' hats, jackets, and shirts, commenting that several of them wore these garments to come to church, or dressed in them during their own ceremonies. In the missionary's view, these forms of imitation seemed like silly childish behavior, but behind the way these items of clothing were worn, we can distinguish a Rapa Nui/Polynesian logic of using garments, consisting of overlapping layers to symbolize status. Eyraud makes a powerful description of the way European outfits are worn:

Naturally, these festivities are an occasion for a show of extraordinary sumptuousness. Everyone attends with their most prized belongings. And so one sees the most eccentric outfits (...) they dress, adorn themselves, and bring everything they possibly can with them. The man who has been able to obtain a dress, wears it as a dress, and if he has two, then he wears two. The woman who has a pair of trousers, a blazer, a jacket, wears them all in the most elegant way possible (Brother E. Eyraud. Cools 1973 par 53-54:20-21).

Eyraud sees the way that the Rapanui use Western garments as 'strange' or 'eccentric', for in the missionary's eyes the islanders do not make proper use of them, with men wearing female clothing and vice versa. In the same manner, father Zumbohn makes fun of the manner in which islanders wore newly acquired clothing from a British ship. He writes:

The following Sunday, our islander, very proud of his acquisition, came to the church costumed as a British Admiral (...) [and] like the good husband he is, he wanted to share the enjoyment of a beautiful outfit with his better half. Thus, in the afternoon in the chapel, we saw the Mrs. appear in the tunic with the beautiful ribbons and shiny buttons (G. Zumbohn, Cools 1973 par 382:157).

The Rapanui's way of dressing followed a nonWestern logic. On all occasions, the most important aspect was to wear several different garments in successive layers, reminiscent of layers of bark cloth with which the islanders made their own textiles. Wearing these garments in overlapping layers, was used only on one particular occasion: Sunday mass, in other words during a ceremonial context. The outfits were then put away and were not used in everyday life. This reveals a particular way of understanding rituality and dress code of the Rapa Nui/Polynesian cultural universe, distinct from the Western way of understanding clothing. 
Garments were also used in this period to identify members of opposing Rapanui bands. Each of the two confederations into which the population was divided -one resident in Hanga Roa and allied with the mission, and the other associated with French merchant Dutrou Bornier, who lived in Mataveri- identified themselves through their clothing, or lack thereof. Those designated as 'pagans' by the missionaries went around 'naked' except for their adornments, while the others wore clothing as prescribed by the mission, i.e., wearing Western clothes. The following extracts from Roussel (1870) letters, relate how the so-called "pagan government" installed in Mataveri was constantly provoking the inhabitants of Hanga Roa.

'The Mataveri dressed as pagans have wished to impose the pagan authority in Hanga Roa' (Cools 1973 par 310:112).

Torometi and his followers in Mataveri have come to provoke the people of Hanga Roa with their gestures, their words, and their pagan clothing (...) many of the people, dressed and painted in the pagan style, moved through the village and made fun of [the villagers], who paid them no attention. (H. Roussel. Cools 1973 par 290:105).

This conduct had also been observed by members of scientific expeditions who called upon the island during the second phase of evangelization (Muñoz 2017). For example, Ignacio Gana, Captain of the O'Higgins, on his visit to the island in January 1870 , mentions having seen two groups, one dressed, the other naked, or dressed in bark cloth:

They are capable of great sacrifice for obtaining a shirt, trousers, or hats. They walk about naked, with the exception of those whom the missionaries have dressed in castoffs from Chile. The others wear blankets made of the above-described mahuto, or dress with strips of cloth. (Gana 1870, in Foerster et al. 2013:440).

In turn, Pierre Loti, in his journal of his visit to the island during the 'reign' of Dutrou Bornier in 1872, recounts that he identified two groups within the island population: one group wearing feather headdresses, and covered with barkcloth, their skin tattooed, while others were dressed in the European style.

...while these clap their hands and enjoy themselves, mingling with us in a familiar way, other persons stand immobile, engrossed with observing us. Upon the rocks (...) another part of the population has climbed, more fearful or more serious, with whom we have not been able to enter into dealings. Men with many tattoos (...) women sitting like statues, wearing on their shoulders a kind of whitened cape, and on their heads, old fashioned combs, cane crowns (Loti 1998:30).

In fact, Pierre Loti mentions that the wives of the men who worked on Bornier's plantations wore muslin dresses imported from Tahiti for them. Loti comments,

There are several women, many of whom are pretty, who are dressed with these muslin tunics of French manufacture that the women of Tahiti use. We discovered that the old Dane ${ }^{8}$ is bringing these objects from Tahiti and distributing them among the wives of those who work on his plantation (Loti 2007 [1872]:42).

Not only were the use of European dresses important, but also the use and importance of some colors. Several authors refer to the symbolism associated with certain colors, particularly white, red and yellow in the contexts of Oceania (Sahlins 1985; Tcherkézoff 2004) and also for Rapa Nui (see for example, Seelenfreund 2013; Seelenfreund and Mardones 2018). Pierre Loti in 1872 describes Borniers widow, Koreto as "the most singular creature in the world, small and plump, with Chinese features such as can be seen on fans. She is well combed and dressed in a tunic of yellow muslin, covered with a red cape, her lips painted" (Loti 1872, in Foerster et al. 2013:463) ${ }^{9}$. When he visited her at the house of Mataveri, he comments that 'she hurried to put on her yellow dress and wrap herself in her red blanket, after which she came out to greet us full of smiles' (Loti 1872, in Foerster et al. 2013:464) ${ }^{10}$. A second version of Loti's account, written later and published in 
1899, has this paragraph removed, however it includes the description of Koreto from January 5, although slightly modified: 'A middle-aged maori, rather pale, who is naturally the most elegant girl on the island, this morning is wearing a yellow muslin tunic with a red woolen travel blanket thrown like a shawl over her shoulders' (Loti 2007 [1872]:116). The above description bears much similarity to one provided by Alphonse Pinart, on a visit to Rapa Nui in April 1877, of the same woman: 'dressed in a 'galia' like the women of Tahiti, the head covered with a panama hat, the shoulders wrapped in Scottish tartan, the feet unshod' (Pinart 1878:236) ${ }^{11}$.

On the basis of the above descriptions on the use of Western garments, we can see how Rapanui society exercised cultural control over both its own cultural elements but also over foreign cultural elements. Indeed, in the case of introduced Western style clothes, we observe a process of appropriation of foreign cultural elements based on the islanders' own decisions. These were guided by a native logic, which defined how these elements and their symbolic value were to be used and placed within the Rapa Nui/Polynesian cultural universe. The way these Western garments were used within Rapanui society also became elements of differentiation between the Rapanui themselves and in the way that Westerners identified them as either the 'pagan band' who dressed in native garments or the 'converts' who wore Western garments, in a manner closer to "proper Western ways".

\section{Discussion and Conclusions}

The process of cultural transformation introduced the Rapa Nui people to the discipline of a new religious doctrine; bringing new ways of understanding the world that included the implementation of a new calendar, a new morality, and a new concept of the body, all reflected in changes in the use of traditional textiles and the incorporation of Western textiles (Thomas 2003). The process of Christianization of the Rapanui people was embedded within a greater colonial enterprise that is part of the broader history of the Pacific. Unlike other islands and archipelagos in which both Protestant and Catholic missionaries established a presence, on Rapa Nui only missionaries from Catholic congregations established themselves.

Within Rapanui studies focusing on the period or Christianization, we find two contrasting positions on the impact these events had on island society. On the one hand, authors such as Métraux (1995 [1941]), Englert (2007) or Cristino (2011) see the slave raids as bringing on a cultural breakdown that represents the beginning of the acculturation process of the islanders, arguing that these events robbed Rapanui society of the specialists who transmitted 'traditional' cultural values, and exposed the people to new cultural forms introduced by Christian evangelization. A different perspective, however, points to the active role played by the islanders in the process of social transformation. Authors such as McCall (1996), Moreno Pakarati (2011), and Foerster et al. (2013) affirm the importance of understanding that the inhabitants of Rapa Nui adapted to Western customs in a strategic manner.

According to McCall (1996), the conversion of Rapa Nui islanders to Christianity is a case of reorganization of some cultural elements, since the ancient beliefs in guardian spirits (akuaku) persisted after the introduction of the Catholic doctrine. The author argues that conversion can be explained by several reasons, especially the strategic conversion of certain chiefs and the belief in the healing power of the missionaries during a time of intense epidemics. Muñoz (2017) adds that evangelization focused primarily on the children, many of them orphaned due to introduced diseases and blackbirding raids, which accelerated the adoption of certain Christian doctrinal principles as well as social differences within Rapa Nui society. Thus, the two belief systems operated in conjunction. According to McCall (1996), the conversion and the adoption of Catholic morality and customs were rather a strategy to obtain certain guarantees, a means to an end. Seeking some distance from this means-to-ends conception, we will employ a dialogical understanding of conversion, seeing it as a process in which the Rapanui people participated actively and consciously, rather than passively.

According to Foerster (2012), the Rapanui consciously took advantage of those who had the material resources they wanted (Foerster 2012). This point should be considered in the context of contact with Europeans, who called on the island in the late 18th and early-to-mid 19th centuries, enabling the islanders to acquire a knowledge that allowed them to improve commercial relations with the ships that continued arriving to the island. McCall (1996) states that "this ability to discern crucial elements in the conduct of the foreigners and then use them for their 
own benefit ...could have originated in their experience with varied nationalities that stayed on the island during the period prior to 1864" (McCall 1996:28).

Although the missionaries saw the Rapanui society as lacking in religious beliefs, it actually had a structure of meaning that enabled them to adapt to the changes brought about by evangelization, through the appropriation of foreign cultural elements represented in Western textiles and Catholic doctrine. Throughout the mission period, the Rapanui people maintained elements of their own culture and generated new cultural forms, while keeping the symbolic logics and structure of their own belief systems, therefore keeping in terms of Bonfill Batalla (2004) a degree of cultural control. As Firth (1959) proposed for the Tikopia people, the figures of Christianity in some way were adopted into a pagan symbolic system that, structurally speaking, would persist. In the same way, Babadzan (1982) expresses, that cultural change should be understood under those conditions, as the transition from traditional thinking to a syncretic thinking.

We propose that the impact of Western culture on the ancient Rapanui culture was most influential during the period of Christianization carried out by the Catholic Mission of Sacred Hearts that operated on the island between 1866 and 1872 . That period ushered in an intense process of cultural transformation that would influence the islanders' way of seeing and understanding the world, opening the way to a hybridization of symbolic elements that enabled the Rapa Nui to understand certain aspects of this new world and the ways it operated.

We pose that the arrival of the missionaries involved an adaptation and a re-reading of ancient cultural forms, based on the appropriation of cultural elements brought by the island's new Western inhabitants. Under the scenario of colonial domination, European textiles were incorporated into the Rapanui belief system as an element for confronting the new Western cultural logics. Thus, through their appropriation, and their use as social markers, Western textiles were used as a new materiality that enabled the islanders to deal with this new cultural space.

In the uses of Western clothing and the cultural decisions taken, Rapanui society in the second half of the 19th century articulated these foreign cultural elements into an appropriated culture, thus exercising cultural control over this sphere of their lives. Although, in the scenario of colonial domination, the cultural control exercised by the different groups was unequal, they were still agents in a conscious decision-making process that positioned the Rapanui in an active space in face of cultural transformations. As we have seen, the possibility of the group to make decisions does not imply absolute freedom of choice, but rather explains how a group chooses certain aspects of cultural life to maintain its existence in the face of a new scenario. In this way, the Western culture appropriated by the Rapanui implied a readjustment of symbolic and emotional aspects, which allowed them to incorporate the appropriated elements. Therefore, the changes that affected the old autonomous culture allowed for the emergence of a new appropriated culture.

Acknowledgments: This work was supported by the Agencia Nacional de Investigación Científica y Desarrollo (ANID), Chile under Grants Fondecyt 1120152 and Fondecyt 1180052 to A.S. We thank Diego Muñoz and Richard Day for critical comments to an earlier versions of this manuscript. All translations from the French are ours. We thank the three anonymous reviewers for their thoughtful comments that helped us to improve our work.

\section{Referencias Citadas}

Aguirre Beltrán, G. 1991. Regiones de Refugio El desarrollo de la Comunidad y el Proceso Dominical en Mestizoamérica. Fondo de Cultura Económica, México DF.

Balandier, G. 1973. Teoría de la Descolonización : Las Dinámicas Sociales. Tiempo Contemporáneo, Buenos Aires.

Babadzan, A. 1982. Naissance d'une Tradition: Changement Culturel et Syncrétisme Religieux aux Iles Australes (Polynésie Française). ORSTOM, Paris.

Babadzan, A. 2003. The gods Stripped are. In Clothing the Pacific, edited by Ch. Colchester, pp. 25-50. Berg, Oxford.

Barth, F. (ed.) 1976. Los Grupos Étnicos y sus Fronteras: la Organización Social de las Diferencias Culturales. Fondo de Cultura Económica, México DF.
Bolton, L. 2003. Gender, status and introduced clothing in Vanuatu. In Clothing the Pacific, edited by Ch. Colchester, pp. 119-139. Berg, Oxford.

Bonfil Batalla, G.1983. Lo propio y lo ajeno. Una aproximación al problema del control cultural. Revista Mexicana de Ciencias Políticas y Sociales 27 (103):183-191.

Bonfil Batalla, G. 1991. La teoría del control cultural en el estudio de procesos étnicos. Estudios sobre las Culturas Contemporáneas IV (12):165-204.

Caranci, C. 1976. La 'Guerra de las Misiones' en Oceanía. Tiempo de Historia 21 (8):92-101.

Cardoso de Oliveira, R. 2007. Etnicidad y Estructura Social. Centro de Investigaciones y Estudios Superiores en Antropología 
Social, Universidad Autónoma Metropolitana, Universidad Iberoamericana, México DF.

Castro, N. 1996. Misioneros y Milenaristas en Isla de Pascua, 18641914. Tesis para optar al Grado Académico de Licenciado en Historia, Facultad de Humanidades, Universidad de Valparaíso, Valparaíso.

Castro, N. 2006. El Diablo, Dios y la Profetisa. Evangelización y Milenarismo en Rapa Nui, 1864-1914. Rapa Nui Press, Rapa Nui.

Conte, J. 1994. Isla de Pascua: Horizontes Sombríos y Luminosos. Centro de Investigación de la Imagen, Santiago.

Cools, A. 1973. L'île de Pâques et la Congrégation des Sacrés Coeurs. Documentation. Unpublished documents, Roma.

Cornell, P. and F. Fahlander 2007. Encounters, Materialities, Confrontations: An Introduction. In Encounters - Materialities Confrontations: Archaeologies of Social Space and Interaction, edited by P. Cornell and F. Fahlander, pp. 1-14. Cambridge Scholars Press, Newcastle.

Cory-Pearce, E. 2005. Surface attraction: Clothing and the mediation of Maori/European relationships. In The Art of Clothing: A Pacific Experience, edited by S. Küchler and G. Were, pp. 73-88. UCL Press, London.

Crane, D. 2012. Fashion and Its Social Agendas: Class, Gender, and Identity in Clothing. University of Chicago Press, Chicago.

Cristino, C. 2011. Colonialismo y neocolonialismo en Rapa Nui: una reseña histórica. In La Compañía Explotadora de la Isla de Pascua. Patrimonio. Memoria e identidad en Rapa Nui, edited by C. Cristino and M. Fuentes, pp. 19-52. Ediciones Escaparate, Concepción.

Delaire, N. 2005. La Escritura sobre el Otro. Los Navegantes, Ilustrados y Misioneros en la Polinesia del Siglo XVII y XIX. Tesis para optar al Grado Académico de Licenciado en Historia. Facultad de Humanidades, Universidad de Valparaíso, Valparaíso.

Dening, G. 1980. Islands and Beaches: Discourse on a Silent Land: Marquesas, 1774-1880. The University of Hawaii Press, Honolulu.

Departamento de Historia Militar 2006. El Ejército y el Pueblo Rapa Nui. Cuaderno de Historia Militar 2:47-114.

Edwards, R. 1918. La Isla de Pascua. Consideraciones expuestas acerca de ella por Mons. R. Edwards Obispo y Vicario Castrense, que la visitó en julio de 1916 y en junio de 1917. Imprenta San José, Santiago.

Edwards, R. 1919. El Apóstol de la Isla de Pascua. José Eugenio Eyraud, Hermano de la Congregación de los Sagrados Corazones. Imprenta Chile, Santiago.

Englert, S. 1978. Idioma Rapanui. Gramática y Diccionario del Antiguo Idioma de la Isla de Pascua. Ediciones de la Universidad de Chile, Santiago.

Englert, S. 1996. Primer siglo Cristiano de la Isla de Pascua. 1864 - 1964. Iberoamericana Vervuert, Madrid.

Englert, S. 2007. La Tierra de Hotu Matu'a. Historia, Etnología y Lengua de la Isla de Pascua. Rapa Nui Press, Rapa Nui.

Ernst, M. and A. Anisi 2016. The Historical Development of Christianity in Oceania. In The Wiley Blackwell Companion to World Christianity, edited by L. Sanneh and M.J. McClymond, pp. 588-604. John Wiley \& Sons, Boston.
Firth, R. 1959. Social Change in Tikopia. Re-Study of a Polynesian Community after a Generation. Allen and Unwin, London.

Fischer, S.R. 2005. Island at the End of the World: The Turbulent History of Easter Island. The University of Chicago Press, Reaktion Books, Chicago.

Foerster, R. 2012. Rapa Nui, Primeras Expediciones Europeas. La Construcción Dialógica de la Isla de Pascua (Siglo XVIII). Rapanui Press, Rapa Nui.

Foerster, R., S. Montecino y C. Moreno 2013. Documentos sobre la Isla de Pascua (1864-1888). Editor general: Rafael Sagredo. Cámara Chilena de la Construcción, Pontificia Universidad Católica de Chile, Dirección de Bibliotecas, Archivos y Museos, Santiago.

Fontana, J. 2000. Europa ante el Espejo. Crítica, Barcelona.

Godoy, M. 2017. Los “colonos polinesios” en Sudamérica: La variante chilena en el tráfico de rapanui a Perú, 1861-1864. In América en Diásporas. Esclavitudes y Migraciones Forzadas en Chile y otras Regiones Americanas (Siglos XVI-XIX), edited by J. Valenzuela. RIL Editores, Santiago.

Jolly, M. 2014. A saturated history of Christianity and cloth in Oceania. In Divine Domesticities: Christian Paradoxes in Asia and the Pacific, edited by H. Choi and M. and Jolly, pp. 429-454. ANU Press, Canberra.

Hendricksen, C. 1991. Dress and the human landscape in Guatemala the case of Tecpan, Guatemala. In Textile Traditions of Mesoamerica and the Andes. An Anthology, edited by M.M. Blum Schevill, J.C. Berlo, E.B. Dwyer, pp. 105-125. University of Texas Press, Austin.

Keesing, R.M. 1984. Rethinking 'Mana'. Journal of Anthropological Research 40 (1):137-156.

King, D. 2011. Food for the Flames. Idols and Missionaries in Central Polynesia. Beak Press, San Francisco.

Küchler, S. y G. Were 2005. The Art of Clothing: A Pacific Experience. UCL Press, London.

Laracy, H. 1976. Marists and Melanesians A History of Catholic Missions in the Solomon Islands. Australian National University Press, Canberra.

Laux, C. 2000. Les Théocraties Missionnaires en Polynésie au XIXe Siècle. Des Cités de Dieu dans les Mers du Sud? L'Harmattan, Paris.

Lee, G., A.M. Altman, and F. Morin 2004. Early Vistors to Easter Island (1864-1877). The Reports of Eugene Eyraud, Hippolyte Roussel, Pierre Loti and Alphonse Pinart. The Easter Island Foundation, Los Osos.

Loti, P. 1988. Isla de Pascua. LOM Ediciones, Santiago.

Loti, P. 2007 [1872]. L'1le de Páques. Journal d'un aspirant de La Flore. Rapanui Press, Rapanui.

Martin, P.M. 1986. Power, cloth and currency on the Loango Coast. African Economic History 15:1-12.

Maude, H.E. 1981. Slavers in Paradise: Peruvian Slave Trade in Polynesia, 1862-1864. Standford University Press, Stanford.

McCall, G. 1996. El Pasado en el presente de Rapanui (Isla de Pascua). In Etnografía. Sociedades Indígenas Contemporáneas y su Ideología, edited by J. Hidalgo, V. Schiappacasse, H. 
Niemeyer, C. Aldunate, P. Mege, pp. 17-46. Editorial Andrés Bello, Santiago.

Medlin, M.A. 1991. Ethnic dress and Calcha Festivals, Bolivia. In Textile traditions of Mesoamerica and the Andes. An Anthology, edited by M.B. Schevill, J.C. Berlo, and E.B. Dwyer, pp. 261279. Garlaand, New York.

Métraux, A. 1995 [1941]. La Isla de Pascua. Laertes, Barcelona.

Moreno Pakarati, C. 2011. El poder político nativo en Rapa Nui tras la muerte de los últimos 'ariki mau. In La Compañía Explotadora de la Isla de Pascua. Patrimonio. Memoria e Identidad en Rapa Nui, edited by C. Cristino and M. Fuentes, pp. 53-73. Ediciones Escaparate, Concepción.

Muñoz, D. 2017. Diaspora Rapanui (1871-2015). L'île de Pâques, le Chili Continental et la Polynésie Française. Une Ethnographie Historique de la Mobilité Dans une Société Transnationale. Doctoral Dissertation, CREDO, EHESS, Paris.

Owyong, Y.S.M. 2009. Clothing semiotics and the social construction of power relations. Social Semiotics 19 (2):191-211.

Pinart, A. 1878. Voyage à l'Ile de Pâques (Océan Pacifique). Le Tour du Monde 36:225-240.

Sahlins, M. 1985. Islands of History. University of Chicago Press, Chicago.

\section{Said, E. 2002. Orientalismo. Debate, Madrid.}

Schneider, J. 1987. The Anthropology of Cloth. Annual Review Anthropology 16:409-448.

Schneider, J. 2006. Cloth and clothing. In Handbook of Material Culture, edited by C. Tilley, W. Keane, S. Kuechler, M. Rowlands, and P.L. Spyer, pp. 203-220. Sage Publications, London, Thousand Oaks, New Delhi.
Seelenfreund, A. and A. Mardones 2018. El doble descubrimiento en Rapa Nui: una mirada desde los textiles. Revista Antropologías del Sur 5 (10):17-38.

Shore, B. 1989. Mana and Tapu. In Developments in Polynesian Ethnology, edited by A. Howard and R. Borofsky, pp. 137-173. University of Hawaii Press, Honolulu.

Sturma, M. 1998. Dressing, undressing, and Early European contact in Australia and Tahiti. Pacific Studies 21 (3):87-104.

Tcherkézoff, S. 2003. On cloth, gifts and nudity: Regarding some European misunderstandings during early encounters in Polynesia. In Clothing the Pacific, edited by C. Colchester, pp. 51-75. Berg, Oxford.

Tcherkézoff, S. 2004. On the boat of Tangaroa. Humanity and divinity in Polynesian-European first contacts: Reconsideration, In First Contacts in Polynesia, The Samoan Case (1722-1848). Western Misunderstandings about Sexuality and Divinity, edited by S. Tcherkézoff, pp.109-153. Journal of Pacific History Monographs / Macmillan Brown Centre for Pacific Studies, Canberra y Christchurch.

Tcherkézoff, S. 2012. More on Polynesian gift-giving: The Samoan Sau and the fine mats (taonga), the Maori hau and the treasures (taonga). HAU Journal of Ethnographic Theory 2 (2):313-324.

Thomas, N. 2003. The case of the misplaced ponchos: Speculations concerning the History of Cloth in Polynesia. In Clothing the Pacific, edited by C. Colchester, pp. 79-96. Berg, Oxford.

Tippet, A. 2005. The Deep Sea Canoe. The Story of Third World Missionaries in the South Pacific. William Carey Library, California.

Weiner, A. and J. Schneider (eds.) 1989. Cloth and Human Experience. Smithsonian Institution Press, Washington DC.

\section{Notas}

1 Easter Island. Rapa Nui is the official name of the island. We use Rapa Nui for the name of the island and Rapanui when referring to the demonym.

2 All translation form the original documents are ours.

3 Muñoz (2017) defines three stages in the evangelization process: The first corresponds to the nine month long visit of brother Eugene Eyraud in 1864, in which he explored the possibilities of establishing a mission on the island; the second stage starting in 1866 and lasting until 1871, corresponds to the period when initial conversion took place and local power structures shifted with the alliance of chiefs with the missionaries and the first settlers. The third stage is marked by missionaries abandoning the island and the mission in 1871 and the transport of 275 converted islanders to Mangareva.

$4 \quad$ Also known as pukuranga. According to Englert (1978: 234) the concept refers to a disciple, student, or follower.

5 Here we use the term mana as analyzed by Shore (1989) who concludes that it is a force always associated with 'generative potency' and vitality which comes from the gods.

6 The concept of tapu is associated with the sacred and with the power of people or objects possessing a lot of mana; the sacred object must be maintained within certain limitations, keeping away from it, and protecting it, as handling it could be dangerous. As a result, it is surrounded by a series of prohibitions, such as not touching it, not looking at it, and not being visible to it (Keesing 1984).
7 The trip of the O'Higgins to Easter Island. Instructions and Journal Letters from the Minister of War and Navy Don Francisco Echaurren to the General Commander of the Navy.

8 He is referring to Christian Schmidt, (1846 - 1913) a German-Dane who came to work on the island with Dutrou Bornier. In 1875, he left the island and went to Tahiti with his Chilean wife, Mercedes Salas (Fisher 2005). When P. Loti met him, he was 25 years old.

9 Our translation from a Spanish text: “....aparece la criatura más singular del mundo, pequeña y regordeta con cara de china, como las que se ven en los abanicos. Está bien peinada y viste una túnica de muselina amarilla, cubierta con una manta encarnada; sus labios tienen pinturas".

10 Our translation from a Spanish text: "se despacha a ponerse su vestido amarillo y envolverse en su manto encarnado, después de lo cual sale a recibirnos con muchas sonrisas".

11 "Gaule" in French, refers to a loose dress or robe, usually white, worn by Tahitian women and known in English as a "mother Hubbard dress." The prototype of these dresses is a model invented by the US fashion industry in the $19^{\text {th }}$ century for women to wear while doing housework. These dresses were introduced to Oceania by Protestant missionaries (Crane 2012). According to Lee et al. (2004:134) the term could also refer to tapa cloth, since the verb "gauler" referts to the beating of a tree with a long pole (guale). Therefore his description would refer to dress made of beaten tapa bark "made in the Tahitian manner". 
